\title{
UJI EFEKTIVITAS EKSTRAK DAUN PEPAYA (Carica papaya) DAN DAUN BABADOTAN (Ageratum conyzoides) TERHADAP MORTALITAS HAMA WALANG SANGIT (Leptocorisa oratorius) PADA TANAMAN PADI PANDANWANGI
}

\author{
Disusun oleh : \\ Ramli**) \\ Denda mahendra*)
}

\begin{abstract}
Abstrak
Tanaman padi merupakan tanaman pangan utama di Indonesia karena lebih dari setengah penduduk Indonesia menjadikan beras sebagai sumber makanan pokok. Kerusakan tanaman padi oleh hama walang sangit seranganya dapat nenurunkan hasil $10-40 \%$ tetapi di serangan yang berat akibat populasi yang tinggi dapat menurunkan hasil sampai $100 \%$ atau puso. Tanaman pepaya (Carica papaya) berpotensi sebagai biopestisida nabati. Berdasarkan penelitian yang dilakukan oleh Konno. Kandungan kimia yang terdapat dalam daun babadotan juga memiliki kemampuan sebagai biopestisida nabati (racun serangga), karena dalam babadotan terkandung senyawa penting atau senyawa metabolit yang bersifat sebagai biopestisida nabati. Penelitian ini adalah penelitian eksperimental dengan menggunakan Rancangan Acak Lengkap (RAL) yang terdiri dari 7 perlakuan yaitu: A : $100 \mathrm{ml}$ ekstrak daun pepaya $+/ 500 \mathrm{ml}$ air(semprot pakan), B : $100 \mathrm{ml}$ ekstrak daun babadotan $/ 500 \mathrm{ml}$ air(semprot pakan) C : $50 \mathrm{ml}$ ekstrak daun pepaya dan $50 \mathrm{ml}$ ekstrak babadotan $/ 500 \mathrm{ml}$ air(semprot pakan) D : $1000 \mathrm{ml}$ ekstrak daun pepaya /500ml air(semprot serangga). E : 100 $\mathrm{ml}$ ekstrak daun babadotan $/ 500 \mathrm{ml}$ air(semprot serangga). Dari hasil penelitian ini kesimpulan diperoleh yaitu: Penggunaan ekstrak daun pepaya dan daun babadotan berpengaruh terhadap mortalitas (kematian) hama walang sangit. Perlakuan yang terbaik pada waktu 24 jam yaitu : perlakuan E (100\% ekstrak daun babadotan $/ 500 \mathrm{ml}$ air dengan metode semprot serangga), sebesar : 63\%. Untuk waktu kematian 50\% hama sasaran ( $\mathrm{LT}_{50}$ ) yang terbaik yaitu perlakuan E $(100 \%$ ekstrak daun babadotan $/ 500 \mathrm{ml}$ air dengan metode semprot serangga), sebesar : 33,07 jam.
\end{abstract}

Kata Kunci : Padi Pandanwangi, Daun Pepaya, Daun Babadotan, Hama Padi Pandanwangi

\begin{abstract}
Paddy plant is a main food in Indonesia because more than half population in Indonesia make rice as staple food source. Damaged paddy plant by Bad-smell grasshopper pest its attacks can reduce the results 10-40\% but in severe attacks due to bigh population can reduce the yield to 100\% or puso. Papaya plant (Carica papaya) potentially as biopesticides nabati. Based on the research which is conducted by Konno. Chemical content that contained in the goatweed leaf also have ability as biopesticides nabati (insecticide) because in goatweed contained important compound or metabolite compound that have character as biopesticides nabati. This research is experimental research by using a completely randomized design (CRD) that consist of 7 treatment that is $A: 100 \mathrm{ml}$ papaya leaf extract $+/ 500 \mathrm{ml}$ water (weft spray), $B: 100 \mathrm{ml}$ goatweed leaf extract $/ 500 \mathrm{ml}$ water (insect spray), C:50 ml papaya leaf extract and $50 \mathrm{ml}$ goatweed leaf extract $/ 500 \mathrm{ml}$ water (insect spray), D: $1000 \mathrm{ml}$ papaya leaf extract $/ 500 \mathrm{ml}$ water (insect spray), E:100 ml goatweed leaf extract $1500 \mathrm{ml}$ water (insect spray), F: 50\% papaya leaf extract $+50 \%$ goatweed leaf extract $1500 \mathrm{ml}$ water, $G$ : control. The result of this research is: The use of papaya leaf extract and goatweed leaf influences UJI EFEKTIVITAS EKSTRAK DAUN PEPAYA (Carica papaya) DAN DAUN BABADOTAN (Ageratum conyzoides) TERHADAP MORTALITAS HAMA WALANG SANGIT(Leptocorisaratorius) PADA TANAMAN PADI PANDANWANGI

RAMLI


the mortality (death) of Bad-smell grasshopper pest. The best treatment at 24 hours, is: treatment E $100 \%$ goatweed leaf extract / $500 \mathrm{ml}$ water with insect spray method), amounting to: 63\%. For the time of death $50 \%$ of the pest target (LT50) is treatment E (100\% goatweed leaf extract / $500 \mathrm{ml}$ water with insect spray method), amounting to: 33.07 hours.

Keywords: Pandanwangi Paddy, Papaya Leaf, goatweed Leaf, Pandanwangi Paddy Pest

*) Alumni Fakultas Sains Terapan UNSUR

**) Dosen Fakultas Sains Terapan UNSUR 


\section{PENDAHULUAN}

Tanaman padi merupakan tanaman pangan utama di Indonesia karena lebih dari setengah penduduk Indonesia menjadikan beras sebagai sumber makanan pokok. Sementara itu kebutuhan beras setiap tahun makin bertambah seiring dengan laju pertambahan penduduk. Pada tahun 2013 kebutuhan beras per kapita mencapai $139,5 \mathrm{~kg} /$ orang dalam waktu setahun, namun pada kenyataannya pada tahun 2014 produksi gabah menurun hanya 69, 87 juta ton gabah kering. Salah satu kendala penurunan produksi padi diakibatkan oleh OPT (Organisme Pengganggu Tanaman). Rata- rata 30\% hasil tanaman hilang karena serangan hama (Ichsan et al., 2017).

Terdapat beberapa jenis hama tanaman padi, seperti hama wereng hijau yang menyebabkan penyakit tungro, walang sangit, kepinding tanah dan wereng coklat. Wereng coklat sudah menyerang tanaman padi di Indonesia sejak pertengahan tahun 1970-an, selain dari pada wereng coklat (Sembiring, 2013)

Walang sangit (Leptocorisa oratorius) adalah serangga yang menjadi hama penting di tanaman budidaya terutama padi. Serangga ini mudah dikenali dari bentuknya yang memanjang, berukuran sekitar $2 \mathrm{~cm}$, berwarna merah dan hitam. Walang sangit adalah anggota ordo Hemiptera. Walang sangit menghisap cairan tanaman dari tangkai bunga (paniculae) sehingga menyebabkan tanaman kekurangan hara dan menguning (klorosis), dan perlahan melemah. Hama ini bukan saja dapat menurunkan hasil tetapi juga menurunkan kualitas gabah seperti bintik-bintik coklat di gabah akibat isapan cairan dari hama tersebut (BBPTP, 2015).

Kerusakan tanaman padi oleh hama walang sangit seranganya dapat nenurunkan hasil $10-40 \%$ tetapi di serangan yang berat akibat populasi yang tinggi dapat menurunkan hasil sampai 100\% atau puso (BBPTP, 2015).

UJI EFEKTIVITAS EKSTRAK DAUN PEPAYA (Carica papaya) DAN DAUN BABADOTAN (Ageratum conyzoides) TERHADAP MORTALITAS HAMA WALANG SANGIT(Leptocorisar oratorius) PADA TANAMAN PADI PANDANWANGI
Upaya pengendalian hama yang selama ini dilakukan masih mengandalkan penggunaan insektisida sintetik. Selain itu petani dalam menggunakan insektisida pada umumnya melebihi dosis anjuran, akibatnya dapat mengganggu ekosistem dan kesehatan manusia. Penggunaan insektisida yang tidak sesuai akan mengganggu keseimbangan musuh alami, menyebabkan resurjensi atau ledakan hama serta resistensi hama. Untuk mendukung pengendalian hama yang berwawasan lingkungan maka perlu dilakukannya pengendalian yang ramah lingkungan. Salah satu cara pengendalian organisme pengganggu tanaman (OPT) adalah dengan menggunakan biopestisida nabati. Beberapa jenis biopestisida nabati yang berasal dari tumbuhan telah banyak dikembangkan untuk mengendalikan hama (BBPTP, 2015).

Tanaman pepaya (Carica papaya) berpotensi sebagai biopestisida nabati. Berdasarkan penelitian yang dilakukan oleh Konno (2004), getah pepaya mengandung kelompok enzim sistein protease seperti papain dan kimopapain. Getah pepaya juga menghasilkan senyawa-senyawa golongan alkaloid, terpenoid, flavonoid dan asam amino nonprotein yang sangat beracun bagi serangga pemakan tumbuhan. Adanya kandungan senyawa-senyawa kimia di dalam tanaman pepaya yang terkandung dapat mematikan organisme pengganggu. Ekstrak daun pepaya (Carica papaya) merupakan salah satu bahan alami yang dapat dijadikan insektisida yang efektif dan aman bagi lingkungan.

Selain penggunaan ekstrak daun pepaya, alternatif pengendalian yang lain yaitu Kandungan kimia yang terdapat dalam daun babadotan juga memiliki kemampuan sebagai biopestisida nabati (racun serangga), karena dalam babadotan terkandung senyawa penting atau senyawa metabolit yang bersifat sebagai biopestisida nabati seperti alkaloid, flavonoid, kumarin, saponin, polifenol, dan minyak atsiri (Kardinan, 2001).

Penelitian tentang pemanfaatan biopestisida nabati berupa ekstrak daun

RAMLI DENDA MAHENDRA 
pepaya dan ekstrak babadotan sudah pernah dilaporkan sebelumnya guna mengendalikan hama walang sangit, sehingga berdasarkan hal tersebut perlu dilakukan tindak lanjut penelitian mengenai pemanfaatan biopestisida nabati untuk mengendalikan hama walang sangit. Penelitian ini diharapkan dapat menemukan jenis biopestisida nabati yang dapat mengendalikan hama walang sangit.

\section{METODE PENELITIAN}

Waktu dan tempat penelitian ini dilakukan di lahan milik MP3C, dan Fakultas Sains Terapan Universitas Suryakancana Cianjur, yang beralamatkan di Kecamatan Cianjur, Kabupaten Cianjur pada bulan juni 2019 .

Alat semprot, gelas ukur, alat saring, pengaduk, penumbuk/blender, timbangan, tali plastik, botol plastik, spidol, label nama dan alat tulis. Sedangkan bahan yang digunakan yaitu air,dari perasan daun pepaya dan daun babadotan. Mempersiapkan daun pepaya dan daun babadotan yang diperoleh dari kebun sekitaran lahan pesawahan milik MP3C.

Walang sangit sebagai serangga uji diperoleh dari lahan budidaya padi di lahan padi Pandanwangi Kabupaten Cianjur, kemudian dipelihara dalam kandang pemeliharaan yang telah berisi tanaman padi.

Mempersiapkan padi untuk pakan walang sangit dimana padi ditanam dalam pot yang telah terisi tanah yang kemudian padi digunakan untuk proses aplikasi.

Pembuatan biopestisida nabati menggunakan daun pepaya dan babadotan,kemudian ditumbuk/diblender hingga halus dan masing-masing ditambahkan 1 liter air. Kemudian disaring dan diperoleh air dari saringan

UJI EFEKTIVITAS EKSTRAK DAUN PEPAYA (Carica papaya) DAN DAUN BABADOTAN (Ageratum conyzoides) TERHADAP MORTALITAS HAMA WALANG SANGIT(Leptocorisa oratorius) PADA TANAMAN PADI PANDANWANGI daun pepaya dan babadotan yang ditumbuk/diblender.

Larutan A : $100 \mathrm{ml}$ ekstrak daun pepaya $/ 500 \mathrm{ml}$ air , B : $100 \mathrm{ml}$ ekstrak daun babadotan $/ 500 \mathrm{ml}$ air, C : $50 \mathrm{ml}$ ekstrak daun pepaya dan $50 \mathrm{ml}$ ekstrak babadotan/500ml air, D : $100 \mathrm{ml}$ ekstrak daun pepaya $/ 500 \mathrm{ml}$ air, $\mathrm{E}: 100 \mathrm{ml}$ ekstrak daun babadotan $/ 500 \mathrm{ml}$ air, F : 50 $\mathrm{ml}$ ekstrak daun pepaya dan $50 \mathrm{ml}$ ekstrak babadotan/500ml air, G : kontrol. Teknik aplikasi yang digunakan yaitu dengan metode kontak/semprot serangga dan celup pakan dengan berbagai konsentrasi biopestisida nabati) untuk memperoleh nilai Mortalitas, dan $\mathrm{LT}_{50}$ yang dihitung setiap 24 jam sampai keseluruhan hama tersebut benar-benar mati.

Penelitian ini adalah penelitian eksperimental dengan menggunakan Rancangan Acak Lengkap (RAL) yang terdiri dari 7 perlakuan yaitu:

1. A : $100 \mathrm{ml}$ ekstrak daun pepaya + $/ 500 \mathrm{ml}$ air(semprot pakan)

2. B : $100 \mathrm{ml}$ ekstrak daun babadotan/500ml air(semprot pakan)

3. C : $50 \mathrm{ml}$ ekstrak daun pepaya dan $50 \mathrm{ml}$ ekstrak babadotan $/ 500 \mathrm{ml}$ air(semprot pakan)

4. D : $1000 \mathrm{ml}$ ekstrak daun pepaya $/ 500 \mathrm{ml}$ air(semprot serangga).

5. E : $100 \mathrm{ml}$ ekstrak daun babadotan $/ 500 \mathrm{ml}$ air(semprot serangga).

6. F : $50 \mathrm{ml}$ ekstrak daun pepaya dan $50 \mathrm{ml}$ ekstrak babadotan/500ml air(semprot serangga).

7. G : Kontrol.

Setiap perlakuan dilakukan 3 kali ulangan. Penelitian ini menggunakan metode kontak (serangga uji disemprot dan dengan celup pakan berbagai konsentrasi biopestisida nabati). Setiap percobaan menggunakan serangga walang sangit berjumlah 10 ekor. 
Tabel 1. Tabel letak pada penelitian ini yaitu:

\begin{tabular}{|c|c|c|c|c|c|c|}
\hline A1 & C1 & K1 & A3 & C3 & F2 & F3 \\
\hline B3 & D1 & E3 & D2 & E2 & K3 & E1 \\
\hline F1 & B1 & A2 & C2 & B2 & D3 & K2 \\
\hline
\end{tabular}

Keterangan huruf $=$ perlakuan, angka = ulangan

Adapun tahap dalam penelitian ini yaitu sebagai berikut:

1. Menyiapkan botol plastik kemudian menempelkan kertas label yang telah diberikan kode setiap perlakuan dan ulangan kebagian tengah botol, selanjutnya memasukkan padi Pandanwangi kedalam tempat yang telah disiapkan. Penggunaan botol plastik dimaksudkan untuk mempermudah pengontrolan setelah pengaplikasian.

2. Pembuatan biopestisida nabati menggunakan daun pepaya dan babadotan, kemudian ditumbuk/diblender hingga halus dan masing-masing ditambahkan $500 \mathrm{ml}$ air. Kemudian disaring dan diperoleh air dari saringan daun pepaya dan babadotan.

3. Mengumpulkan serangga uji dari kandang pemeliharaan dengan menggunakan tangan.

4. Memasukkan serangga uji ke dalam botol plastik yang berisikan padi Pandanwangi dengan 10 serangga uji perbotol plastik dan setiap botol dilubangi bagian tengahnya menggunakan kawat panas untuk memastikan serangga uji mendapatkan udara untuk bernapas dan setiap lubang berukuran kecil yang berjumlah lebih dari 5 lubang perbotol plastik.

5. Melakukan pengamatan terhadap perilaku walang sangit setelah aplikasi uji penambahan dosis ekstrak dari kedua jenis tanaman.

6. Mencatat jumlah serangga uji yang mati pada setiap perlakuan pencatatan dilakukan setiap 24 Jam Selama 48 jam.
Pengamatan dilakukan setiap 24 jam selama 48 hari setelah aplikasi. Pengamatan meliputi mortalitas serangga uji, dan waktu kematian (periode letal).

1. Mortalitas

$$
\text { Persentase mortalitas }
$$
serangga uji dihitung dengan menggunakan rumus (Susilo et al., 1993), yaitu:

$\mathrm{P}=\mathrm{A} / \mathrm{B} \times 100 \%$,

Keterangan:

$\mathrm{P}=$ persentase kematian serangga uji.

$A=$ jumlah serangga uji mati selama 48 jam pengamatan.

$B=$ jumlah serangga uji awal per unit percobaan.

2. Lethal Time $50 \%$

Penentuan $\mathrm{LT}_{50}$ dilakukan untuk mengetahui berapa waktu yang dibutuhkan untuk mengakibatkan kematian hama sebanyak 50\% dengan menggunakan probit analisys.

Data yang diperoleh diolah menggunakan bantuan software microsoft excel dan Minitab. Data yang diperoleh dari pengamatan mortalitas dilakukan dengan sidik ragam (ANOVA) jika terdapat pengaruh dilakukan uji lanjut dengan taraf kepercayaan $95 \%$ atau a $5 \%$ pada program software SPSS. LT $_{50}$ di analisis dengan menggunakan probit analisis pada program software minitab.

Pada penelitian yang dilakukan diperoleh data kematian walang sangit berupa kematian walang sangit pada rentang waktu 24 jam, 36 jam, dan 48 jam. Dengan menggunakan tujuh perlakuan berbagai konsentrasi. 
Tabel 2. Pengaruh konsentrasi ekstrak daun pepaya dan daun babadotan. terhadap rerata jumlah mortalitas walang sangit pada 24 jam, 36 jam, 48 jam.

\begin{tabular}{|c|c|c|c|c|}
\hline \multirow[t]{2}{*}{ perlakuan } & \multicolumn{4}{|c|}{$\begin{array}{l}\% \text { Mortalitas pada waktu } \\
\text { pengamatan }\end{array}$} \\
\hline & $24 \mathrm{Jam}$ & 36 & jam & 48 jam \\
\hline $\begin{array}{l}\text { A } 100 \% \text { ekstrak daun pepaya } / 500 \mathrm{ml} \text { air metode } \\
\text { semprot serangga }\end{array}$ & $3,3 a$ & $57 \mathrm{~b}$ & & $100 \mathrm{a}$ \\
\hline $\begin{array}{l}\text { B } 100 \% \text { ekstrak daun babadotan } / 500 \mathrm{ml} \text { air } \\
\text { metode semprot serangga }\end{array}$ & $3,3 \mathrm{a}$ & $37 \mathrm{ab}$ & & $93 a$ \\
\hline $\begin{array}{l}\text { C } 50 \% \text { ekstrak daun pepaya }+50 \% \text { ekstrak daun } \\
\text { babadotan } / 500 \mathrm{ml} \text { air metode semprot } \\
\text { serangga }\end{array}$ & $6,7 a$ & $43 \mathrm{ab}$ & & $100 \mathrm{a}$ \\
\hline $\begin{array}{l}\text { D } 100 \% \text { ekstrak daun pepaya } / 500 \mathrm{ml} \text { air metode } \\
\text { semprot pakan }\end{array}$ & $6,7 a$ & $53 \mathrm{ab}$ & & $100 \mathrm{a}$ \\
\hline $\begin{array}{l}\text { E } 100 \% \text { ekstrak daun babadotan } / 500 \mathrm{ml} \text { air } \\
\text { metode semprot pakan }\end{array}$ & $10 \mathrm{a}$ & $63 \mathrm{~b}$ & & $100 \mathrm{a}$ \\
\hline $\begin{array}{l}\text { F } 50 \% \text { ekstrak daun pepaya }+50 \% \text { ekstrak daun } \\
\text { babadotan } / 500 \mathrm{ml} \text { air }\end{array}$ & $3,3 a$ & $37 \mathrm{ab}$ & & $100 \mathrm{a}$ \\
\hline G Kontrol & $0 \mathrm{a}$ & $6,7 a$ & & $40 \mathrm{a}$ \\
\hline
\end{tabular}

Dari Tabel 2. menunjukkan aplikasi beberapa konsentrasi ekstrak daun pepaya dan daun babadotan. Belum memberikan pengaruh terhadap mortalitas Walang sangit hasil pengamatan pada 24 jam setelah aplikasi, biopestisida dengan perlakuan 1 (100\% ekstrak daun pepaya $/ 500 \mathrm{ml}$ air metode semprot serangga) menujukkan kematian serangga uji 3,3\%, belum terlihat pengaruh dari ekstrak daun pepaya. perlakuan ke 2 (100\% ekstrak daun babadotan $/ 500 \mathrm{ml}$ air metode semprot serangga) kematian serangga uji $3,3 \%$, belum terlihat pengaruh dari daun ekstrak daun babadotan. perlakuan ke 3 (50\% ekstrak daun pepaya $+50 \%$ ekstrak daun babadotan $/ 500 \mathrm{ml}$ air metode semprot serangga) kematian serangga uji 6,7\%, belum terlihat pengaruh dari 2 campuran ekstrak daun. perlakuan 4 (100\% ekstrak daun pepaya $/ 500 \mathrm{ml}$ air metode semprot pakan) menujukkan kematian serangga uji $6,7 \%$, belum terlihat pengaruh dari ekstrak daun pepaya. perlakuan ke 5 (100\% ekstrak daun babadotan $/ 500 \mathrm{ml}$ air metode semprot pakan) kematian serangga uji $1 \%$, belum terlihat pengaruh dari ekstrak daun babadotan. perlakuan ke 6 (50\% ekstrak daun pepaya $+50 \%$ ekstrak daun babadotan $/ 500 \mathrm{ml}$ air metode semprot pakan) kematian UJI EFEKTIVITAS EKSTRAK DAUN PEPAYA (Carica papaya) DAN DAUN BABADOTAN (Ageratum conyzoides) TERHADAP MORTALITAS HAMA WALANG SANGIT(Leptocorisa oratorius) PADA TANAMAN PADI PANDANWANGI serangga uji 3,3\%, belum terlihat pengaruh dari 2 campuran ekstrak daun. perlakuan ke 7 (kontrol) kematian serangga uji $0 \%$, sama sekali belum terlihat pengaruh.

Memberikan pengaruh terhadap mortalitas Walang sangit hasil pengamatan pada 36 jam setelah aplikasi, biopestisida dengan perlakuan 1 (100\% ekstrak daun pepaya $/ 500 \mathrm{ml}$ air metode semprot serangga) menujukkan kematian serangga uji $57 \%$, sudah terlihat pengaruh dari ekstrak daun pepaya. perlakuan ke 2 (100\% ekstrak daun babadotan $/ 500 \mathrm{ml}$ air metode semprot serangga) kematian serangga uji $37 \%$, sudah mulai terlihat pengaruh dari daun ekstrak daun babadotan. perlakuan $3 \quad(50 \%$ ekstrak daun pepaya $+50 \%$ ekstrak daun babadotan $/ 500 \mathrm{ml}$ air metode semprot serangga) kematian serangga uji 43\%, sudah mulai terlihat pengaruh dari 2 campuran ekstrak daun. perlakuan 4 $(100 \%$ ekstrak daun pepaya $/ 500 \mathrm{ml}$ air metode semprot pakan) menujukkan kematian serangga uji 53\%, sudah terlihat pengaruh dari ekstrak daun pepaya. perlakuan ke $5 \quad(100 \%$ ekstrak daun babadotan $/ 500 \mathrm{ml}$ air metode semprot pakan) kematian serangga uji 63\%, sudah sangat terlihat pengaruh dari ekstrak daun babadotan. perlakuan $6(50 \%$ ekstrak

RAMLI DENDA MAHENDRA 
daun pepaya $+50 \%$ ekstrak daun babadotan $/ 500 \mathrm{ml}$ air metode semprot pakan) kematian serangga uji 37\%, sudah terlihat pengaruh dari 2 campuran ekstrak daun. perlakuan ke 7 (kontrol) kematian serangga uji $6,7 \%$, sama sekali belum terlihat pengaruh.

Memberikan pengaruh terhadap mortalitas Walang sangit hasil pengamatan pada 48 jam setelah aplikasi, biopestisida dengan perlakuan 1 (100\% ekstrak daun pepaya $/ 500 \mathrm{ml}$ air metode semprot serangga) menujukkan kematian serangga uji $100 \%$, terlihat pengaruh dari ekstrak daun pepaya. perlakuan ke $2 \quad(100 \%$ ekstrak daun babadotan $/ 500 \mathrm{ml}$ air metode semprot serangga) kematian serangga uji $93 \%$, terlihat pengaruh dari daun ekstrak daun babadotan. perlakuan 3 (50\% ekstrak daun pepaya $+50 \%$ ekstrak daun babadotan $/ 500 \mathrm{ml}$ air metode semprot serangga) kematian serangga uji $93 \%$, terlihat pengaruh dari 2 campuran ekstrak daun. perlakuan $4(100 \%$ ekstrak daun pepaya $/ 500 \mathrm{ml}$ air metode semprot pakan) menujukkan kematian serangga uji $100 \%$, terlihat pengaruh dari ekstrak daun pepaya. perlakuan $5(100 \%$ ekstrak daun babadotan $/ 500 \mathrm{ml}$ air metode semprot pakan) kematian serangga uji 100\%, sudah sangat terlihat pengaruh dari ekstrak daun babadotan. perlakuan $6(50 \%$ ekstrak daun pepaya $+50 \%$ ekstrak daun babadotan $/ 500 \mathrm{ml}$ air metode semprot pakan) kematian serangga uji 100\%, terlihat pengaruh dari 2 campuran ekstrak daun. perlakuan ke 7 (kontrol) kematian serangga uji $40 \%$, tidak terlihat memberikan dampak yang lebih banyak terhadap mortalitas walang sangit.

Menurut (Lumowa, S, V, V. 2011). Penelitian efektivitas ekstrak babadotan (Ageratum conyzoides L.) terhadap tingkat kematian larva instar IV Spodoptera litura F. telah dilaksanakan di Laboratorium Kimia Kayu Fakultas Kehutanan, dan di Laboratorium Pendidikan Biologi Fakultas Keguruan dan Ilmu Pendidikan Universitas Mulawarman Samarinda 30 Juni 2010 sampai dengan 8 oktober 2010. Penelitian bertujuan untuk mengetahui efektivitas ekstrak babadotan (A. conyzoides) terhadap tingkat kematian larva instar IV S. litura instar. Kegiatan penelitian terdiri dari uji pendahuluan dan uji lanjutan. Uji pendahuluan digunakan 6 perlakuan yaitu konsentrasi $0 \%, 0,001 \%, 0,01 \%, 0,1 \%$, $1 \%$ dan 10\%; sedangkan uji lanjutan terdiri dari 4 perlakuan yaitu konsentrasi $0 \%, 5 \%, 10 \%$ dan $20 \%$. Hasil penelitian menunjukkan bahwa pada uji pendahuluan dengan perlakuan konsentrasi $10 \%$ menghasilkan tingkat kematian larva uji sebesar $60 \%$; sedangkan pada uji lanjutan dengan perlakuan konsentrasi $20 \%$ menghasilkan tingkat kematian larva uji sebesar $100 \%$ dengan lama kematian larva uji 26-60 menit (lumowa sonja 2011).

Menurut Ardina (2007) dalam penelitiannya tentang ekstrak etanol:air (1:3) daun pepaya, gel ekstrak daun pepaya efektif terhadap Staphylococcus epidermidis sebanyak 8,65×109 CFU/ml, tetapi tidak efektif terhadap Propionibacterium acne sebanyak 2,7×107 CFU/ml. Di dalam ekstrak daun pepaya terkandung papain (keratolitik, antimikroba) dan karpain (antibakteri), yang diduga dapat berperan sebagai senyawa aktif sediaan antijerawat (Ardina, 2007). Kandungan kimia dari tanaman pepaya (Carica papaya L) adalah sebagai berikut: Daun: enzim papain, alkaloid karpaina, pseudo-karpaina, glikosid, karposid dan saponin, sakarosa, dekstrosa, dan levulosa. Alkaloid karpaina mempunyai efek seperti digitalis.

Pengamatan mortalitas walang sangit dilanjutkan pada pengamatan LT50, menggunakan pobit analysis pada program software minitab. Lethal time LT50 dilakukan untuk mengetahui berapa waktu yang dibutuhkan untuk mengakibatkan kematian hama sebanyak 50\%. Hasil analisis LT50 didapat sebagai estimase atau nilai rata-rata kematian pada masingmasing perlakuan, maka dapat dilihat pada tabel 3. 
Tabel 3. hasil uji probit analysis efektivitas biopestisida nabati dari ekstrak daun pepaya dan daun babadotan.

\begin{tabular}{|c|c|}
\hline PERLAKUAN & $\mathrm{LT}_{50}(\mathrm{jam})$ \\
\hline A : $100 \mathrm{ml}$ ekstrak daun pepaya $/ 500 \mathrm{ml}$ air & 34,72 \\
\hline B : 100 ml ekstrak daun babadotan $/ 500 \mathrm{ml}$ air & 37,92 \\
\hline C : $50 \mathrm{ml}$ ekstrak daun pepaya dan $50 \mathrm{ml}$ ekstrak babadotan $/ 500 \mathrm{ml}$ air & 36,72 \\
\hline D : $100 \mathrm{ml}$ ekstrak daun pepaya $/ 500 \mathrm{ml}$ air & 34,60 \\
\hline $\mathrm{E}: 100 \mathrm{ml}$ ekstrak babadotan $/ 500 \mathrm{ml}$ air & 33,07 \\
\hline $\mathrm{F}: 50 \mathrm{ml}$ ekstrak daun pepaya dan $50 \mathrm{ml}$ ekstrak babadotan $/ 500 \mathrm{ml}$ air & 36,85 \\
\hline G : kontrol & 50,22 \\
\hline
\end{tabular}

Keterangan : Semakin kecil nilai LT maka semakin efektif suatu biopestisida nabati yang digunakan, sehingga semakin singkat pula waktu yang dibutuhkan untuk mengendalikan hama walang sangit $50 \%$.

Usaha pengendalian hama yang dilakukan oleh petani di Indonesia masih sering menggunakan insektisida sintetis sehingga menyebabkan efek samping yang serius seperti terjadinya pencemaran udara, tanah dan air, matinya organisme non sasaran (musuh alami), dan terjadinya resurjensi hama (Pandit, 2006).

Salah satu kelebihan dari penggunaan daun pepaya sebagai insektisida nabati adalah mudah didapat, aman terhadap tanaman, sulit menimbulkan kekebalan pada hama. Penelitian yang dilakukan oleh Juliantara (2010), menyatakan bahwa pestisida nabati daun pepaya efektif dalam pengendalian ulat dan hama penghisap. Berdasarkan penelitian yang dilakukan oleh Mawuntu (2015).

Berdasarkan penelitian yang dilakukan oleh Julaily dan Setyawati (2013), hama dapat resisten jika penyemprotan pestisida dilakukan secara berkala. Selain itu, faktor yang mempengaruhi kurang efektifnya penggunaan insektisida nabati adalah mudahnya pestisida terdegredasi jika terkena sinar matahari (Idris, 2016). Untuk mempertahankan kandungan toksik dalam insektisida nabati sebaiknya diaplikasikan saat pagi atau sore hari.

UJI EFEKTIVITAS EKSTRAK DAUN PEPAYA (Carica papaya) DAN DAUN BABADOTAN (Ageratum conyzoides) TERHADAP MORTALITAS HAMA WALANG SANGIT(Leptocorisa oratorius) PADA TANAMAN PADI PANDANWANGI
Menurut Zakiyah dan Hoesain (2013), menjelaskan bahwa terdapat keterkaitan antara intensitas serangan walang sangit dengan hasil panen. Hasil panen yang tinggi diakibatkan oleh intensitas serangan walang sangit yang rendah. Dan jika hasil panen rendah diakibatkan oleh intensitas serangan walang sangit yang tinggi.

\section{KESIMPULAN}

Penggunaan ekstrak daun pepaya dan daun babadotan berpengaruh terhadap mortalitas (kematian) hama walang sangit.

Perlakuan yang terbaik pada waktu 24 jam yaitu : perlakuan E $(100 \%$ ekstrak daun babadotan $/ 500 \mathrm{ml}$ air dengan metode semprot serangga), sebesar : 63\%. Untuk waktu kematian 50\% hama sasaran $\left(\mathrm{LT}_{50}\right)$ yang terbaik yaitu perlakuan E $(100 \%$ ekstrak daun babadotan $/ 500 \mathrm{ml}$ air dengan metode semprot serangga), sebesar : 33,07 jam. 


\section{DAFTAR PUSTAKA}

Anonim, 2000, Pedoman Pengendalian Hama Terpadu Holtikultura, Direktorat Perlindungan Tanaman Pangan, Agromedia Pustaka, Jakarta.

Ardina, Y. 2007. Development of Antiacne Gel Formulation and Minimum Inhibitory Concentration Determination From Carica Papaya Leaves Extract (Carica papaya Linn.). http://digilib.itb.ac.id/gdl.php. 23 Agustus 2012.

BBPTP, 2015. Developments and Challenges of Resistant Varietal Breeding Program in Brown Planthopper Management in Indonesia (34) : 187-193.

Dalimarta \& Hembing. (1994). Atlas tumbuhan obat Indonesia. Jakarta: Trubus Agriwidia.

Dinata,A. 2007. Basmi Lalat dengan Jeruk Nipis

http://www/litbang.depkes.go.id /lokaciamis/artikel/lalatarda.htm.

Effendi et al., (2010), jamur entomopatogen asal tanah lebak di sumatera selatan dan potensinya sebagai agensia hayati walang sangit (leptocorisa oratorius) $102: 154-161$.

Harahap, I. S. dan B. Tjahjono, B. 2004.Pengendalian Hama Penyakit Padi. Penebar Swadaya. Jakarta.114 hlm.

Ichsan, N, C., Bakhtiar, Efendi dan Sabaruddin. 2017. Karakteristik Hasil Varietas/Genotipe Padi (Oriza Sativa L.) Terpilih Di Lahan Tadah Hujan. Prosiding Seminar Nasional Biotik.336-346.

Ichsan M. 2013. Karakteristik viabilitas benih padi beberapa varietas asal aceh dan varietas unggul nasional.. Skripsi. Fakultas Pertanian. Universitas Syiah Kuala. Banda Aceh.

Julaily., N, Mukarlina, dan Setyawati, T, R. 2013. Pengendalian Hama pada

UJI EFEKTIVITAS EKSTRAK DAUN PEPAYA (Carica papaya) DAN DAUN BABADOTAN (Ageratum conyzoides) TERHADAP MORTALITAS HAMA WALANG SANGIT(Leptocorisa oratorius) PADA TANAMAN PADI PANDANWANGI
Tanaman Sawi (Brassica juncea L.) Menggunakan Ekstrak Daun Pepaya (Carica papaya L.). Jurnal Protobit.2(3):171-175.

Kalshoven. 1981. The Pests of Crops in Indonesia. Revised and translated by P.A. Van der Laan. P.T. Ichtiar Baru Van Hoeve. Jakarta.701 hlm.

Kardinan, A. 2001. Pestisida Nabati Ramuan dan Aplikasi Cetakan ke3. Penebar Swadaya: Jakarta

Konno, K, 2004, 'Papain Protects Papaya Trees from Hervivorous Insect: Role of Cysteine Proteases in Latek' Plant Journal vol. 37, no. 3, hal. 370- 378.

Lumowa, S, V,V. 2011. Efektivitas Ekstrak Babadotan (Ageratum conyzoides L.) Terhadap Tingkat Kematian Larva Spodoptera litura F.Jurnal eugenia 17(3):186192.

Masyarakat Pelestari Padi Pandanwangi Cianjur (MP3C), (2015), Buku Persyaratan Permohonan Pendaftaran Indikasi Geografis Beras Pandanwangi Cianjur, Cianjur.

Mawuntu, m. s. c. 2015. Efektivitas ekstrak daun sirsak dan daun pepaya dalam pengendalian plutella xyloseta L. (lepidoptera; Yponomeutidae) pada tanaman kubis dikota tomohon . ilmiah sains, 16(1) : 24-29.

Pandit, I. 2006. Resiko Pestisida Nabati. http://www.balopost.co.id/ balipostcetak/2006/4/5/02.htm.

Pratimi et al 2011. Fluktuasi Populasi Walang Sangit Leptocorisa oratorius F. (Hemiptera : Alydidae) Pada Komunitas Padi Di Dusun Kepitu, Sleman, Daerah Istimewa Yogyakarta (13) : 54-59.

Samsudin. 2008. Virus Patogen Serangga Bioinsektisida Ramah Lingkungan. Diakses Desember 2014 dari http://Lembagapertanian sehat/

RAMLI DENDA MAHENDRA 
develop Useful innovation for farmers Rubrik.

Susilo FX, Hasibuan R, Nordin GL \& Brown GC. 1993. The concept of threshold density in insect pathology: A Theoretical and experimental study on Tetranychus - Neozygites mycosis. Prosiding Makalah Simposium Patologi Serangga I.

Sembiring 2013. sistem pakar diagnosa penyakit dan hama tanaman padi (111) : 6-7.

Soranta, W, E. 2009. Aktivitas Antibakteri Ekstrak Etanol Daun Pepaya (Carica papaya L) Terhadap Escherichia coli dan Staphylococcus aureus Multiresisten Antibiotik. Skripsi. (Universitas Muhammadiyah Surakarta).1-20.

Untung, 2001. Diktat Dasar-dasar Ilmu Hama Tanaman.

Wudianto, R, 1992, Petunjuk Penggunaan Pestisida, Penebar Swadaya, Jakarta. 